\title{
Kuambü: poética e política em uma festa xinguana ${ }^{1}$
}

\author{
ANTONIO GUERREIRO \\ UNIVERSIDADE ESTADUAL DE CAMPINAS (UNICAMP), CAMPINAS/SP, BRASIL \\ HTTPS://ORCID.ORG/OOOO0-0002-2986-3622 \\ MARINA PEREIRA NOVO \\ UNIVERSIDADE ESTADUAL DE CAMPINAS (UNICAMP), CAMPINAS/SP, BRASIL \\ HTTPS://ORCID.ORG/oOoo-0002-9843-4258
}

\section{Introdução}

O objetivo deste artigo é discutir algumas relações entre poética e política entre os Kalapalo, um povo de língua karib do Alto Xingu (MT, Brasil), a partir de cantos pertencentes a uma festa chamada kuambü. Distintamente de outros rituais da região, com repertórios fixos e muitas vezes em outras línguas, o kuambü tem como cerne a composição individual e improvisada de cantos feitos ao mesmo tempo para ferir e divertir, atacar e se defender, zombar e alegrar. Eles geralmente lidam com temas espinhosos da vida cotidiana, das relações intra- e inter-aldeias, e das relações com os não indígenas. Tais cantos mobilizam relações que fazem e desfazem alianças características da política xinguana (Franchetto 1997) e podem ser vistos como reflexões críticas sobre os desafios da contínua criação da socialidade de uma aldeia. Os próprios Kalapalo dizem que o kuambü "é como a política”, porque as pessoas "discutem" e "querem mostrar quem está certo". Mutua Mehinaku também argumenta nessa direção, sugerindo que, no kuambü, é possível "sentir como a política é feita por meio do canto no exercício da liberdade de criticar" (Mehinaku 2010:85). Do que seria feita, então, essa política, e como ela pode ser descrita a partir da criatividade poética e performática característica desse ritual? O kuambü nos convida a realizar um deslocamento de foco dos estudos sobre a política alto-xinguana, e sobre as políticas ameríndias de

1 Agradecemos à leitura atenta do manuscrito por Bruna Franchetto, que levantou questóes e comentários valiosos, os quais foram incorporados à versão final deste texto. Também agradecemos a leitura dos/as pareceristas anônimos/as, que apontaram questões importantes para a finalização do artigo e para reflexões futuras. Pesquisa financiada pela Fundação de Apoio à Pesquisa do Estado de São Paulo - FAPESP (Processos no. 2012/20200-1; 2018/07747-8; 2013/26676-0; 2018/25900-8) 
modo mais amplo. Enquanto a antropologia política xinguana e das terras baixas vem tradicionalmente se ocupando dos problemas da chefia, do poder e do Estado, o kuambü dá acesso a elementos de uma "micropolítica" da vida cotidiana, indispensável para a contínua produção da vida coletiva.

Este trabalho está centrado no kuambü enquanto um gênero verbo-musical e tem como foco apenas um conjunto limitado de cantos. Apesar de já termos visto filmagens feitas pelos Kalapalo e outros xinguanos e contarmos com descrições de interlocutores sobre essa festa, esse ritual não é feito há mais de dez anos na aldeia Aiha, a maior aldeia Kalapalo, onde a pesquisa vem sendo conduzida ${ }^{2}$. Por essa razão, aspectos de sua organização e de sua performance serão, aqui, deixados de lado. Nos limitamos a descrever e traduzir alguns de seus cantos, procurando identificar e discutir elementos-chave de sua forma poética, de sua semântica e de sua pragmática.

\section{Uma festa ambígua}

Os Kalapalo são um dos grupos que vivem na região conhecida como Alto Xingu, habitada por uma dezena de povos pertencentes a diferentes agrupamentos linguísticos. Estes povos compartilham um conjunto de valores que orientam a produção de pessoas, as relações nos grupos locais e as relações supralocais que, por sua vez, marcam uma diferença entre a "gente xinguana”, que cultiva um ethos de não agressividade pública, e seus vizinhos a leste e ao norte, tidos como "bravos” pela prática da guerra (Basso 1973; Franchetto 2011; Franchetto \& Heckenberger 2001; Gregor 1990; Menezes Bastos 1983).

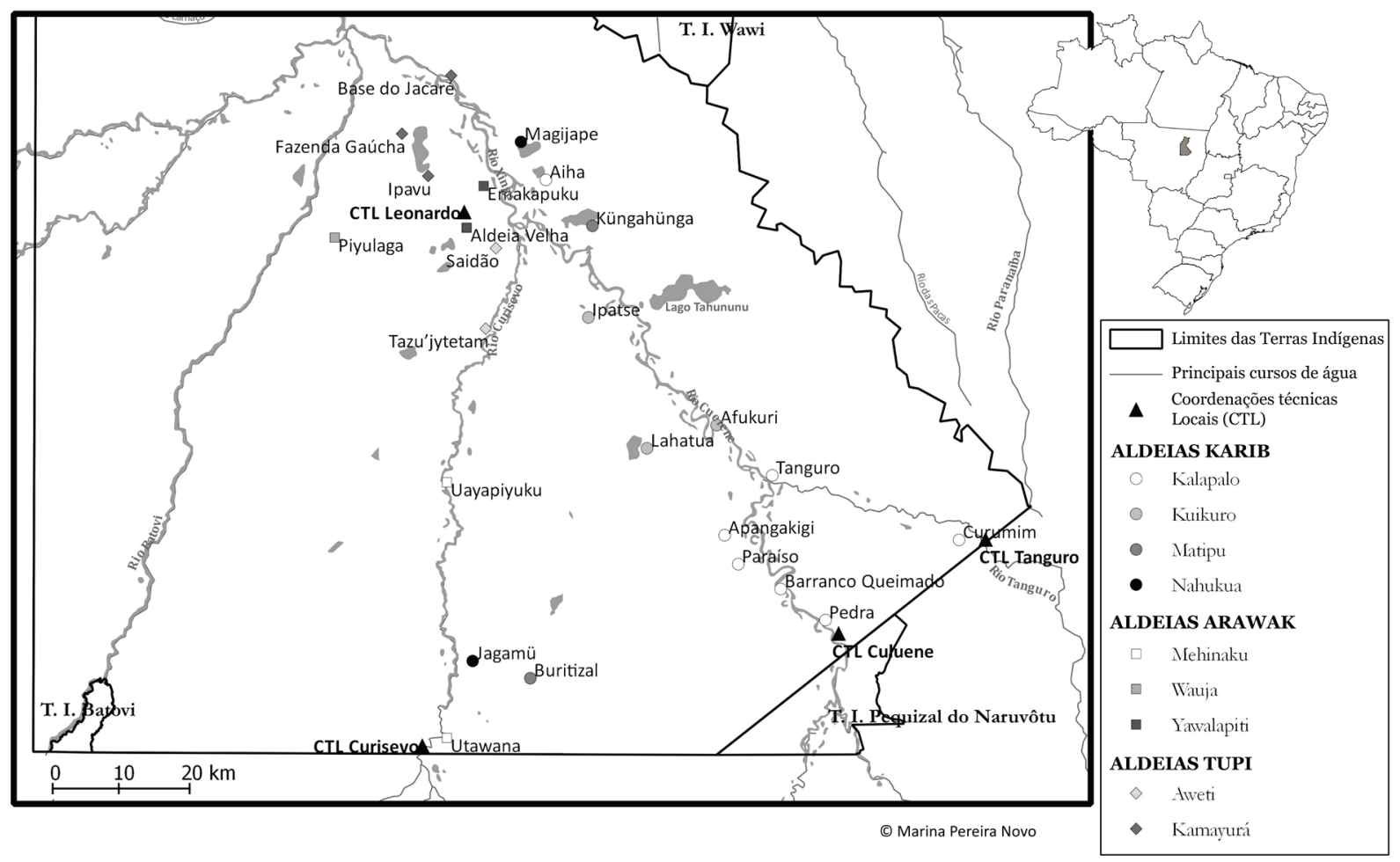

Figura 1: mapa do Alto Xingu. Fonte: Marina Pereira Novo.

2 Não obstante, ocorreu um kuambü em uma pequena aldeia kalapalo em 2017, e a festa continua ocorrendo entre outros povos alto-xinguanos. 
O kuambü é um dos vários rituais de máscaras ${ }^{3}$ realizados pelos alto-xinguanos e, como tal, está associado a um processo de adoecimento, diagnóstico e cura mediado pelo xamanismo (Barcelos Neto 2008). Quando alguém tem sua alma raptada por um "Hiper-Ser" (itseke), a cura depende de um processo que envolve a identificação do espírito causador da doença e a realização de um ritual para ele. Alguns desses Hiper-Seres possuem rituais próprios, enquanto outros, que não possuem festas específicas, podem aparecer para o doente durante o sonho, ou para o xamã durante o transe, utilizando máscaras de alguma festa. Este é o caso do kuambü, que não é um Hiper-Ser em particular, mas um tipo de máscara usada por seres aquáticos. Caso o Hiper-Ser causador da doença de alguém apareça utilizando essa máscara, é um sinal de que essa festa deve ser realizada. A festa “domestica” o Hiper-Ser, antes agressor, transformando-o, por meio da oferta de alimentos, bebida e da performance ritual, em um parente adotivo do ex-doente: o doente se torna dono/pai das máscaras.

Imagens de máscaras do kuambü estão presentes na literatura desde os relatos de Karl von den Steinen (1940) e, até onde sabemos, trata-se de uma festa realizada por todos os povos alto-xinguanos, e também pelos Bakairi, que viveram na região do Alto Xingu até o início do século XX (Barros 2003).

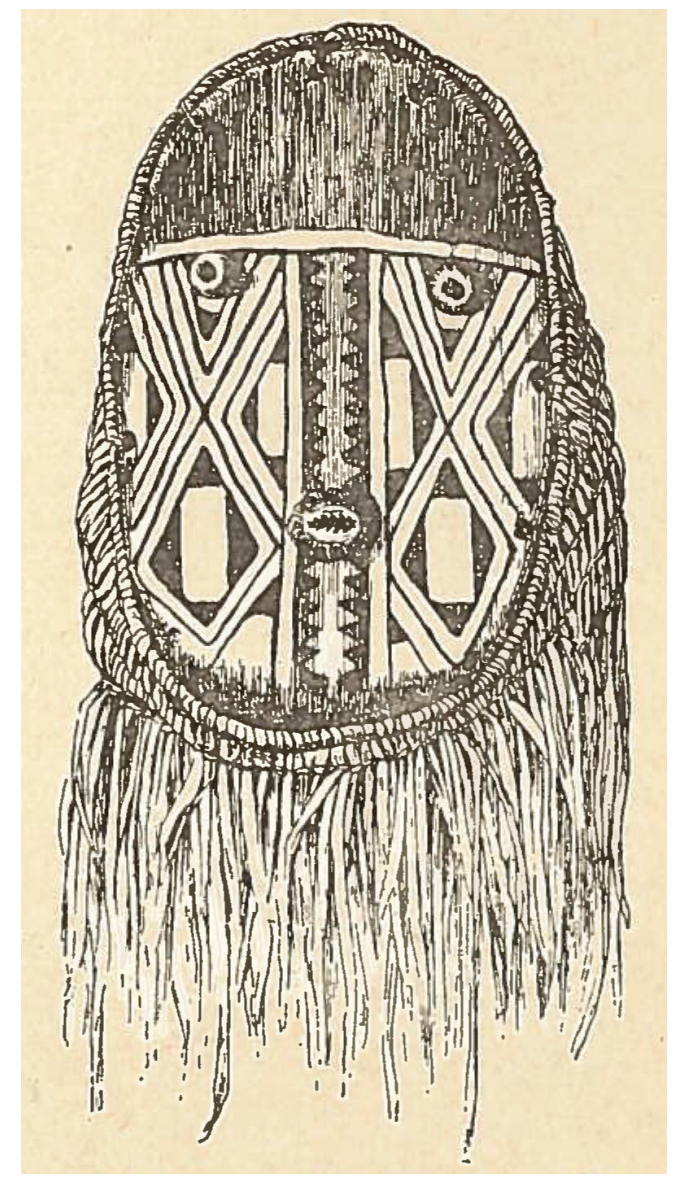

Figura 2: máscara do kuambü, registrada por Von den Steinen (1940: 401) entre os Aweti em 1887.

3 Apesar de tratarmos aqui todos esses rituais como "rituais de máscaras", alguns deles possuem outros tipos de apetrechos, que podem ser saiotes de palha, chocalhos, flautas ou clarinetes. Retomaremos essa questão adiante.

4 Seguimos aqui a proposta de tradução de Bruna Franchetto (2018), que coloca em primeiro plano o caráter "excessivo" desses seres - muito grandes ou muito pequenos, muito distantes, excessivamente poderosos, com alguma característica corporal exacerbada, etc. Outra tradução comum na literatura para itseke é "espírito". 
A primeira descrição desta festa no Alto Xingu foi feita entre os próprios Kalapalo, por Ellen Basso. Segundo ela, no kuambü "the effective structure of social life is gradually eroded by the conditions of a performative process that ends in a remarkable display of anarchic chaos" (Basso 1985: 258). Basso destaca que o ritual contrasta com outros pelo fato de que ele enfatiza "the individuality of each performer and personal antagonisms revealed by gossip" (Ibid, loc. cit.). Ao invés das performances focalizarem na beleza da musicalidade de tradições coletivas de cantos, como em outras festas, elas colocam em primeiro plano "fofocas", "palavras ruins" (Ibid:259). Trata-se de um repertório de cantos que não é fixo, mas criativamente renovado a cada vez que a festa é realizada. Assim, pode-se cantar tanto "cantos dos antigos" quanto cantos criados pelos próprios cantores para aquela ocasião específica.

Seja qual for o caso (mas principalmente quando se trata de cantos "novos"), os cantos podem provocar raiva, vergonha e dor. Ao mesmo tempo, uma caracterização caricata dos cantores adiciona graça ao ritual, amenizando ou oferecendo um contraponto à gravidade dos assuntos dos cantos. Basso descreve, por exemplo, como pessoas acusadas de serem sovinas dançavam e cantavam carregando inúmeros objetos pessoais, pendurados no corpo ou amarrados em bastões, e como o parente de um homem perseguido por feitiçaria uma vez se vestiu com partes de um uniforme militar e dançou apontando uma arma para as pessoas. Como ela diz, “(...) there is no attempt to make oneself a beautiful ritual object (as is done during other rituals). During the Kwambï, people try to embarrass the gossipers by appearing as innocently absurd as possible" (Basso 1985:260). Ainda assim, uma tônica agressiva se sobrepóe, evidenciada tanto pela dinâmica das canções (as pessoas podem compor cantos para responder a canções de acusação dirigidas a elas, produzindo disputas poéticas), quanto por elementos da estética corporal (como o ato de portar signos de agressividade, como arcos, espingardas ou, no caso das mulheres, pesadas mãos de pilão).

Franchetto também apresenta e comenta alguns cantos kuambü entre os Kuikuro (outro povo de língua karib, do Alto Xingu) e argumenta que eles se situam em um contínuo em relação à fala, que “está presente, embora constrangida na estrutura e forma poéticas" (Franchetto 1986:250). Esta fala, diferentemente das falas bonitas da praça (os discursos rituais dos chefes), e dos cantos multilíngues e pouco inteligíveis dos rituais interaldeias, gravita em torno de assuntos particulares, como as relações entre amantes e a fofoca (Ibid:265; 267). Franchetto sugere que o kuambü seria um "carnaval entre muros" (Franchetto 1997:59), em que as pessoas se apresentam fantasiadas, personificando alegorias do que criticam. Os motivos seriam "mexericos" sobre "amores e amantes, adultérios, feitiçaria, os problemas da afinidade, a presença dos brancos" (Ibid, loc. cit.), uma trama pela qual "se tece a política intra e inter-aldeias nos jogos faccionais em que se articula a disputa pelo prestígio e pelo poder” (Ibid:62).

Outra discussão sobre essa mesma festa, na sua versão aweti (tupi), foi feita por Marina Vanzolini (2015). Os Aweti chamam a festa de morezowagetu, que a autora traduz como "debate". Essa tradução chama atenção para a organização dos cantos na forma frequente de diálogos, geralmente de tom conflituoso, que ocorrem em vários níveis: internamente aos cantos, com a citação de fofocas e acusações das quais o cantor procura se defender; e entre o compositor de um canto de acusação e seu acusador, que pode responder por meio de outro canto (Vanzolini 2015:332). Vanzolini apresenta traduções de cantos executados por homens e argumenta que eles tratariam de dois temas: relações amorosas e acusações de feitiçaria (Ibid:328). Ela destaca a centralidade de uma oposição entre os gêneros em cantos com 
ambos os temas, pois mesmo naqueles sobre feitiçaria "É comum as mulheres aparecerem no papel de acusadoras, ou eventualmente na figura de uma filha que foi ou será vítima de feitiçaria, ou da amante que sentirá saudade do cantor, quando este for embora em decorrência das acusações” (Ibid:329).

O caráter generizado do ritual apareceria no modo como os homens e mulheres aweti dançam: os primeiros, portando sua flecha/pênis ${ }^{5}$, e as segundas, com mãos de pilão (objetos que, como nota Vanzolini, também lembram a borduna, principal arma dos Aweti antes da xinguanização). Logo, "Homens e mulheres assim 'armados' sugerem que a oposição entre acusadores e acusados tematizada em quase todos os cantos pode ser análoga a uma oposição entre os sexos” (Ibid:332). Esta festa tematizaria, portanto, a feitiçaria como parte de uma "guerra" entre homens e mulheres que se desenrola desde o tempo mítico, quando os primeiros tomaram delas as flautas sagradas e o domínio sobre a vida pública/ritual, relegando as mulheres à periferia e ao domínio do parentesco. Recorrendo a mitos sobre a vida no tempo em que as mulheres eram donas não só das flautas, mas de todos os bens culturais, e de como o roubo dos instrumentos rituais é vingado pelas mulheres no ritual do Jamurikumã ${ }^{6}$, Vanzolini argumenta que os mitos representam a socialidade feminina como uma na qual inexistem distinções, enquanto a socialidade do ritual seria, ao contrário, aquela capaz de produzir macrodistinções (entre humanos e não humanos, homens e mulheres, entre os diferentes grupos alto-xinguanos, entre os grupos que partilham uma mesma vida ritual e inimigos, etc.). Enquanto aos homens caberia, desde o roubo, produzir as diferenças da vida social por meio do ritual, às mulheres caberia produzir o parentesco, um modo de identificação marcado pela intensa circulação de coisas, palavras e substâncias. Contudo, como argumenta a autora, esse processo de identificação nunca é completo, e o parentesco revela uma face perigosa, que por meio da inveja, do ciúme e da proximidade excessiva, pode se converter em feitiçaria. "A guerra entre os sexos em torno do feitiço expressa nos cantos rituais de morezowagetu pode ser entendida, desse modo, como mediação insolúvel - infinito debate - entre o modo relacional próprio ao parentesco e à feitiçaria, e o modo relacional próprio ao ritual e à vida pública" (Ibid:338). O ritual apresentaria, de forma controlada, fraturas da vida cotidiana, do parentesco, como parte dos problemas de se tentar conciliar a socialidade masculina com a socialidade feminina, a socialidade do ritual com a do parentesco.

$\mathrm{O}$ argumento de Vanzolini parece tocar no ponto central do kuambü e abre uma agenda de investigações que ainda precisam ser conduzidas sobre as relações entre gênero, parentesco e política no Alto Xingu. Neste artigo, pretendemos dialogar com este argumento, explorando outras qualidades do kuambü que parecem importantes para ampliar sua compreensão: a primeira refere-se à presença marcante de outros temas nos cantos kalapalo, como a chefia e os brancos, para além das relações amorosas e da feitiçaria já apontadas na literatura; outra, refere-se à poética própria aos cantos kuambü, que apresentam uma estrutura muito similar, um vocabulário recorrente e fórmulas que permitem a sua contínua variação/ invenção; e, por fim, o modo como este ritual mobiliza afetos contraditórios, como alegria e dor, graça e raiva, articulando-se, por meio deles, à micropolítica da vida cotidiana, algo que pode ser explorado pela constante referência dos cantores aos contextos de composição e execução original de cada canto.

5 Pois "flecha" e "pênis" são designados em aweti por uma mesma palavra. O mesmo vale para o kalapalo e as demais variedades do karib alto-xinguano.

6 Ritual em que as mulheres ocupam o centro da aldeia, performando cantos e danças. Para uma etnografia deste ritual, ver Mello (2004). 


\section{Cantar para outros, cantar sobre si}

Como a maioria dos rituais realizados pelos Kalapalo, o kuambü foi aprendido de Hiper-Seres. Aposa era um grande xamã kalapalo, que viveu na aldeia Hagagikugu ("Lugar de Seriemas"). Ele era "parente de Hiper-Seres" (itseke hisuüttgü), como são os xamãs capazes de entrar em transe. Mas Aposa era especial e não precisava entrar em transe para interagir com os espíritos. "Com seu próprio corpo" ( tibü ake), como se diz, ele ia até suas moradas. Ele costumava ir até o fundo das águas buscar comida e bebida, que ofertava para as pessoas como “o beiju dos seus irmãos" e "o mingau de seus irmãos". Ele tinha uma filha, já adulta e casada, chamada Kügümbü, que também se tornou xamã. Assim como seu pai, ela transitava livremente no mundo dos espíritos. Um dia, ela foi para o fundo das águas buscar comida. No centro da aldeia dos peixes, viu ali alguns casais de máscaras e ouviu seus cantos: jakuikatu, kuambü, müma e piju. Depois de ver a dança dos seres aquáticos mascarados, ela voltou para sua aldeia. No dia seguinte, ela conversou com o chefe e disse ter encontrado algo "divertido". Ela contou para o chefe sobre as festas, que depois anunciou à aldeia que "nossa irmã" lhes mostraria "nossos Hiper-Seres". Kügümbü foi ao centro da aldeia, e explicou às pessoas como fazer as máscaras. Depois de prontas, as máscaras foram pintadas: as máscaras-homens (maridos) de preto, com jenipapo, e as máscaras-mulheres (esposas) de vermelho, com urucum. Em seguida ela cantou os cantos de cada uma delas, começando com jakuikatu. Somente depois ela apresentou Kuambü, com o seguinte canto ${ }^{7}$ :

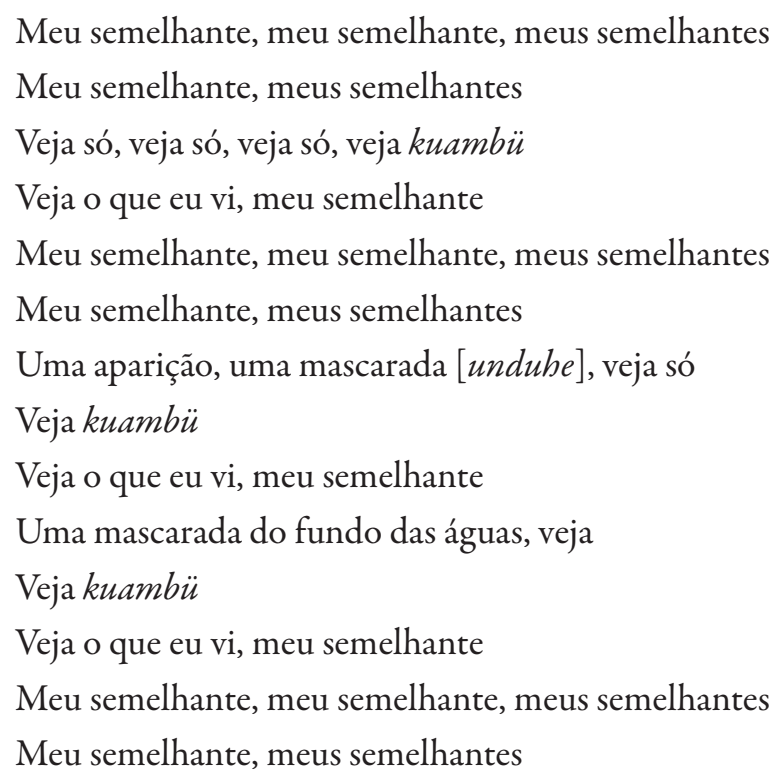

Nesse canto, Kügümbü (o cantor chamou a atenção para a proximidade entre seu nome e o nome da festa) apresenta o kuambü como um unduhe dos peixes. Optamos por traduzir unduhe por "mascarada", e não apenas por "festa" (como é comum), porque nem toda festa é unduhe. Ao mesmo tempo em que é o nome de uma festa específica (ver Novo 2018), o termo unduhe pode ser utilizado para fazer referência a qualquer atividade ritual que envolva Hiper-Seres e apetrechos rituais (em sua

7 Por se tratar de um conhecimento ritual valioso, este canto não será transcrito em kalapalo. Apresentamos apenas uma tradução, reduzindo ao mínimo as repetições paralelísticas. 
maioria, máscaras, mas também podem ser flautas, clarinetes ou outras "vestimentas", como no caso da festa chamada unduhe, cujos apetrechos utilizados são saiotes de palha). Muitos desses eventos são, efetivamente, considerados "festas" pelos Kalapalo, mas alguns não o são, pelo fato de não possuírem cantos em sua execução e, por isso, não "alegrarem" as pessoas. Assim, os unduhe de Ahasa (Hiper-Cabaça Canibal) e Atugua (Hiper-Redemoinho), por exemplo, não poderiam ser chamados de "festas" (ailene), segundo os Kalapalo. Ainda que não se tratem, portanto, exclusivamente de eventos em que se usa máscaras, optamos pelo termo "mascarada" por entender que possibilita tratar desses rituais sem generalizar a forma-festa para além de onde ela realmente é aplicável. Em paralelo a isso, apesar da grande sobreposição entre o que a antropologia costuma chamar de ritual e o que os povos indígenas costumam chamar de festa (Perrone-Moisés 2015), preferimos seguir usando um conceito específico de ritual para recobrir todos os eventos (sejam festas ou não) nos quais formas relacionais tidas como antagônicas são sobrepostas, produzindo contextos interativos complexos próprios para a ação ritual, dos quais esta extrai sua eficácia (Berthomé \& Houseman 2010; Houseman \& Severi 1998).

A narrativa esclarece que o kuambü é parte de um conjunto de mascaradas aquáticas que deveriam ser tratadas em conjunto, mas infelizmente não dispomos de dados para tanto. Cabe apenas destacar que a socialidade dos peixes é frequentemente comparada à socialidade dos humanos, em oposição às socialidades dos animais terrestres (inimigos/afins potenciais dos vivos) e das aves (inimigos/ afins potenciais dos mortos). As festas aquáticas são, em sua maioria, festas que põem em evidência a socialidade do grupo local, e o kuambü não é diferente. Ao final do artigo apontaremos sugestões de comparação com outros rituais alto-xinguanos.

Os cantos analisados a seguir formam parte de um corpus de 80 cantos documentados com um cantor e uma cantora da aldeia Aiha, dos quais 54 foram transcritos, traduzidos e analisados. Todos os cantos documentados estavam acompanhados de explicações sobre seus sentidos e contextos de composição, que servem de pano de fundo para os argumentos aqui apresentados. As transcrições e traduções foram feitas por Yamalui Mehinaku, e posteriormente revisadas pelos autores com Ugise Kalapalo, com participação pontual de outros colaboradores kalapalo. O que se segue deve ser visto apenas como ensaios de tradução, ainda em fase experimental.

Como já foi dito, o centro das atenções do kuambü é formado por canções que tocam em temas sensíveis das relações pessoais. Compostos na língua dos executores e ouvintes, eles contrastam com a maioria dos cantos rituais alto-xinguanos, que são em línguas ininteligíveis para os Kalapalo, como arawak ou tupi. Mesmo para os falantes dessas línguas, os cantos possuem conteúdos semânticos limitados, e sua ênfase recai sobre seus contornos rítmicos e melódicos. Já os cantos de kuambü, como são abertos à composição individual e construídos como provocações/autodefesas, estão entre os poucos que podem ser compreendidos - como também é o caso do tolo, conjunto de cantos femininos de origem kalapalo ${ }^{8}$. Eles também diferem de outros repertórios por seu modo de organização. A maioria das

8 Trataremos mais desse gênero de cantos adiante. Para análises do tolo, ver Franchetto (1997, 2018) e Franchetto e Montagnani (2011). 
canções e músicas instrumentais xinguanas está organizada em conjuntos formados por suítes. Esses conjuntos são fechados, e as peças de cada suíte ( $g e p a$ ) são organizadas em uma ordem, assim como as suítes podem, dependendo do ritual, ser ordenadas entre si (Fausto, Franchetto \& Montagnani 2011). Peças musicais organizadas dessa forma são tinapisinhü, “ordenadas" ou “enfileiradas”. Já o conjunto de canções do kuambü é aberto a frequentes invenções, e as peças não formam conjuntos nem são ordenadas - são tratadas, portanto, como tapehagalingo, "espalhadas". Por fim, se nos repertórios fechados de outros rituais as canções são atribuídas a seres míticos ou coletivos, no kuambü a autoria das canções é individual, podendo ser compostas e executadas tanto por homens quanto por mulheres. Em termos de sua organização, portanto, ele representa o avesso dos rituais multicomunitários.

Alguém pode compor um canto questionando, ou ridicularizando, o que outro disse sobre ele/a ou algum parente, ou expondo alguma ação reprovável. As acusações são feitas sempre de modo indireto, sem explicitar a quem se dirigem. Todavia, para qualquer ouvinte que conheça o contexto de sua composição, os alvos são facilmente identificados. Também é possível compor cantos fazendo caricaturas de si mesmo ou de outros, apenas para provocar o riso da audiência. Alguns desses cantos podem cair nas graças do público, tornando-se conhecidos em aldeias vizinhas. Ao fazê-lo, podem ser lembrados e executados no futuro, em outras festas. Nesses casos, a autoria dos cantos é sempre lembrada. Há ainda cantos muito antigos, cuja autoria é desconhecida, mas que permanecem na memória coletiva e são acompanhados de exegeses que revelam seu sentido original e seu contexto de composição. Com efeito, a quase totalidade dos cantos registrados foram compostos por outras pessoas: o cantor disse nunca ter composto um canto próprio, apesar de conhecer um longo repertório, enquanto a cantora disse ter composto vários, mas aceitou registrar apenas duas de suas composições. Dos cantos de outros, alguns são de pessoas desconhecidas (ngiholo, "antigos") e outros de parentes próximos, como pais, tios, tias e avôs. Nesse último caso, porém, para nossos registros, foram executados apenas cantos de parentes já falecidos. Isso sugere que a execução de cantos fora do contexto do ritual pode ter efeitos indesejáveis. Acusar alguém, ou defender-se de uma acusação, fora do contexto do ritual, significa atualizar essa acusação; e cantar o canto de alguém ainda vivo, seja qual for o seu teor, é o mesmo que se intrometer em seus assuntos particulares.

O kuambü e seus cantos são associados a sentimentos ambíguos. Trata-se de uma festa: ailene, uma "alegração", ou ailoho, algo "feito para alegrar", e alguns de seus cantos e as performances corporais exageradas ou caricatas são tidas como "divertidas/gostosas", tapoginhü. Ao mesmo tempo, várias pessoas ressaltam que a festa e seus cantos, pelo teor acusatório, também são "feios/ruins" (hesinhü) e "dolorosos" (sininhü). Como a cantora explicou, o kuambü é doloroso porque as pessoas "brigam" ou "disputam", imütonkgijü (lit., "ficam face a face").

Nessa festa há dois tipos de composição. Um deles é referido pela palavra verbal tolotelü, de difícil tradução, mas que faz referência aos cantos feitos sobre outras pessoas, com algum destinatário específico. Outras composições são ditas "costuradas", ataheĩtsügü, que, no contexto do kuambü, referem-se a cantos feitos sobre si mesmo ou algum parente próximo. Tolotelü é formada a partir da raiz tolo, que pode significar "pássaro", “xerimbabo" ou "amante”. Com efeito, parece haver alguma ressonância entre esses três sentidos possíveis. As aves são os xerimbabos por excelência dos alto-xinguanos, e qualquer 
outro animal doméstico também é chamado de tolo. Amantes também são tolo uns dos outros, porque manter uma relação amorosa é equivalente a um processo mútuo de "domesticação", feito pela contínua sedução, por meio das relações afetivas, sexuais e da oferta de presentes. Tolo também é como se chama um enorme conjunto de cantos femininos, que se originaram entre os antepassados dos Kalapalo quando viviam às margens do grande lago Tahununu (localizado ao sul de Aiha, também na margem direita do Rio Culuene; cf. mapa acima) e se difundiram entre os karib xinguanos (ver Franchetto 2018)9.

Segundo Franchetto, a palavra tolotelü é formada pela raiz tolo acrescida do morfema -te, um “verbalizador transitivo com beneficiário" (Franchetto 2018:32). Os cantos tolo, assim, "são 'feitos para ir para alguém"” (Ibid, loc. cit.). São como cantos-mensagens, enviados pela executora a um destinatário explícito ou apenas insinuado. O mesmo vale para as composições tolotelü do kuambü, mas que possuem um estilo bastante diferente das canções femininas tolo e uma forma particular de identificar o destinatário na estrutura do canto (voltaremos a essa comparação adiante).

Para entender os possíveis sentidos de tolotelü, cabe pensar sobre o campo semântico da palavra tolo. $\mathrm{Na}$ cosmologia xinguana, os pássaros ocupam duas posições possíveis em relação aos humanos: podem aparecer tanto como inimigos quanto parentes. Os pássaros são os inimigos arquetípicos dos mortos, com quem entram em guerra durante os eclipses. Ao mesmo tempo, pássaros que foram xerimbabos dos humanos em vida recebem os mortos no céu como parentes adotivos (as almas dos pássaros tornam-se filhas adotivas das almas humanas) e os ajudam no difícil trajeto até a aldeia dos mortos (repleto de perigos que podem extinguir as almas humanas; cf. Guerreiro 2015a) e nas guerras contra as aves (outras, perigosas). Entre os vivos, os xerimbabos (sejam aves ou outros animais) também ocupam uma posição ambígua: são filhos adotivos de seus donos (oto), mas filhos não humanos, que podem manifestar sua condição animal por meio do comportamento, podendo fugir ou até mesmo agredir ${ }^{10}$. Vale lembrar que, para os alto-xinguanos, o tolo arquetípico é a harpia, que era mantida em grandes gaiolas cônicas feitas com madeira, havendo relatos de pessoas que foram mortas no trato com essas aves. Os amantes também são marcados por uma ambiguidade semelhante: mesmo muito bem cuidados e satisfeitos, podem se envolver com outros/as namorados/as, com quem talvez venham a se casar. Adicionalmente, tomados por ciúmes, os/as amantes podem enfeitiçar seus/suas namorados/as. Às vezes tolotelü é descrito como uma ação/composição feita entre primos cruzados. No cotidiano, primos cruzados devem ser tratados com o mesmo tipo de respeito e generosidade devido aos irmãos, mas frequentemente mantêm relações jocosas em público. Quando alguém patrocina um trabalho coletivo (como a abertura de uma roça, ou a construção de uma casa), um primo cruzado pode pedir um pagamento especial pelo trabalho. Enquanto todos recebem alimento, o primo que fez o pedido deverá receber algum objeto que ele próprio escolherá. Espera-se que o primo tenha bom senso e peça objetos de pouco valor, mas às vezes as pessoas exageram, constrangendo o devedor. O primo, em contrapartida, deve trabalhar mais que os outros, ajudando na coordenação do trabalho. Além disso,

9 Franchetto (2018) descreve os tolo como "curtos poemas cantados" (Ibid:24), nos quais as mulheres jogam com a duplicidade de sentido da palavra tolo ("amante" e "bichinho-de-estimação") e cantam sobre temas como "saudade, desejo de fuga, vaidade, orgulho, assim como relações de antagonismo e disputa entre mulheres, entre homens, entre homens e mulheres, entre, afinal, parentes” (Ibid:33-34).

10 Como Carlos Fausto argumenta a respeito da maestria na Amazônia, as relações entre donos/mestres e seus xerimbabos é sempre ambígua e oscilante (Fausto 2008). 
no hagaka, ritual de arremesso de dardos ${ }^{11}$, primos cruzados distantes de diferentes povos falam publicamente coisas jocosas e, muitas vezes, agressivas, uns sobre os outros, e se enfrentam arremessando dardos com ponta de cera de abelhas. Os Kalapalo se referem às relações jocosas entre primos cruzados pelo verbo handilü ( $h a-N d i-l \ddot{u}$, primo.cruzado-VBLZ-PNCT), que traduzem como "sacanear". Aqui, optamos por traduzi-lo como "aprimalhar", como um modo de resguardar a dependência da sacanagem da condição de primos cruzados. Na falta de uma expressão adequada em português, essa tradução permite evocar a jocosidade ligeiramente agressiva entre primos associada à mera revelação dessa relação.

Segundo a cantora, a associação entre tolo e handilü pode ser encontrada na narrativa de origem dos rios. Não havia água na terra, apenas no céu, guardada em uma grande panela dentro da casa ritual da aldeia do chefe do Povo-Estrela. Sol o engana para roubar sua água e pede ajuda dos Hiper-Seres aquáticos para quebrar a panela. A panela se quebra, a água começa a descer para a terra e leva junto todos aqueles Hiper-Seres, que se tornariam os donos dos rios. Porém, Sol não deixa toda a água escorrer, apenas o suficiente para formar lamaçais e, com isso, os donos dos rios quase morrem (que era a real intenção de Sol). Nesse momento, o pássaro tomonho, primo do Sol, o ofende, e este, surpreso e irritado, acaba deixando o restante da água escorrer, formando os rios. Sol então pergunta quem o havia "aprimalhado", e os seres da água respondem que havia sido "seu irmão" (fazendo referência a tomonho). Para se vingar, Sol veste tomonho com a máscara piju que ele tinha sobre sua cabeça, e esta toma o lugar de seu rosto. Desde então, qualquer ofensa pública é considerada tolo, equivalente ao que tomonho (uma ave, tolo) fez ao Sol.

Tolo parece recobrir, assim, categorias marcadas por ambiguidades, por uma sobreposição entre identidade e alteridade, cuidados e agressividade, proximidade e distância: as aves, na cosmologia, são inimigos ou aliados; os xerimbabos são filhos adotivos, mas não deixam de ser animais que, mesmo deixando-se domesticar pelos cuidados, podem manifestar sua ferocidade; as relações entre os amantes, apesar de envolverem pessoas muito próximas, costumam se manter ocultas e guardam os perigos do ciúme, da traição e da feitiçaria; e os primos, por fim, são um tipo particular de "irmão", "igual mas diferente", com quem se coopera e se compete. Tolotelü, então, implica em enviar cantos-mensagens que evidenciam a alteridade oculta, perigosa e inescapável de quem está muito próximo. Por esse motivo, mesmo desviando do sentido mais literal sugerido pela morfologia da palavra, tolotelü talvez possa ser traduzido como "apassarinhar", como um modo de evocar ambiguidades marcadas no campo semântico da palavra tolo, especialmente visíveis no episódio envolvendo Sol e seu primo-ave ${ }^{12}$.

Como já afirmamos, além dos cantos referidos como tolotelü, o repertório do kuambü é composto também por outro tipo de cantos, considerados ataheĩtsügü, "costurados". De forma geral, todo canto composto é considerado "costurado", porém, quando os Kalapalo utilizam essa palavra ao falar sobre o kuambü, eles quase sempre se referem a cantos diferentes de tolotelü: canções feitas sobre si mesmo, em geral para se defender de acusações ou, nas formas mais leves, criar um estereótipo de si. Vemos então dois tipos de composição no kuambü, em oposição. Tolotelü (“apassarinhar”) é uma ação

11 Regionalmente conhecido como Jawari. Sobre essa festa, ver Menezes Bastos (2013).

12 Esta proposta se inspira em outra feita por Basso (1985), que traduz tolo como “birding”, sem se aprofundar, contudo, nos possíveis sentidos dessa tradução. 
transitiva, em que a composição é provocativa/agressiva para um destinatário. Pode-se dizer, nesse caso, “uhaü tolotega uheke (Eu estou apassarinhando meu primo cruzado)". Já aheĩjü (costurar) aparece como uma ação reflexiva e defensiva: "utaheĩtsa hegei (Eu estou compondo sobre mim)".

\section{Feitiçaria, afinidade e chefia: sobre os cantos do kuambü}

Os cantos são melodicamente diferentes uns dos outros, mas mesmo para ouvidos leigos fica clara a existência de um estilo. Cada peça é aberta com a execução, em tom baixo, do som vocal he com um vibrato lento, e fechada em tom alto com o vocalismo kao, geralmente prolongando o final e com repetição (kaoooo!, kaooo!). O conteúdo do canto é seu corpo ou tronco (ibü), geralmente composto por um conjunto de dois ou três versos seguidos de uma bifurcação (itsîkumbapügü) ${ }^{13}$, depois da qual retorna-se (opijü) para os versos iniciais. Os cantos também apresentam com frequência o que chamam de etimbetoho (lit., "que serve para chegar"), ou destinatário. Um destinatário frequente são as mulheres (que aparecem sob a forma comum itaó ou como itaón $i^{14}$ ), ora no final de cada verso, no final de um bloco de versos que se $b i$ furcaram, ora no final da canção (nos últimos dois casos, com o mesmo tom grave e o vibrato da abertura). Outro destinatário comum é uagingo, "meu semelhante", ou uagingoni ("meus semelhantes"), que podem aparecer nos mesmos lugares que itã̃ e itaõni. Vejamos um exemplo de canto abaixo:

1.

Tü itsekegüi tina uatehe uhunalü uheke?

Tü itsekegüi tina uatehe ubunalü uheke?

Itaõni

Itaôni

Osiha tueke ulimoha tueke

Osiha tueke uhamoha tueke

Tü itsekegüi tina uatehe uhunalü uheke?

Tü itsekegüi tina uatehe ubunalü uheke?
Com o Hiper-Ser de quem eu poderia saber? Com o Hiper-Ser de quem eu poderia saber?

Mulheres

Mulheres

Vá, mate meus filhos, mate

Vá, mate meus sobrinhos, mate

Com o Hiper-Ser de quem eu poderia saber?

Com o Hiper-Ser de quem eu poderia saber?

As duas primeiras linhas são o corpo do canto, enquanto as duas linhas seguintes indicam o destinatário, que aqui é o coletivo das mulheres, itaõni (que os Kalapalo e outros xinguanos traduzem como "mulherada”, opção tradutiva usada por Vanzolini 2015; aqui, propomos utilizar "mulheres", para evitar eventuais conotações pejorativas que o termo "mulherada" pode vir a ter nas relações de gênero locais). As outras duas linhas que se seguem são a bifurcação do canto, seguida por um retorno aos versos do corpo. Como veremos, os cantos costumam ser variações dessa estrutura básica. Este é o tolotelü de um xamã, no qual ele ameaça seus inimigos feiticeiros. Ao mesmo tempo em que os desafia a matar seus parentes (filhos e sobrinhos), ele ironicamente deixa claro que ele próprio, sendo um xamã, descobrirá a identidade do assassino por meio de seu Hiper-Ser auxiliar. Descobrir a identidade de um feiticeiro é abrir caminho para a vingança, o que faz do canto uma ameaça antecipada, com a expectativa de proteger o xamã e seus parentes.

13 Os Kalapalo comparam as bifurcações aos refrões de músicas sertanejas.

14 De acordo com Franchetto (comunicação pessoal, 2020), /-ni/ seria "uma sílaba filler para adaptar o verso à sua estrutura melódica". 
O destinatário explícito do canto acima é o coletivo de mulheres, mas que se encontra no lugar de um destinatário implícito: um homem feiticeiro. Esse tipo de formulação é recorrente no kuambü, em que os homens, mesmo quando claramente se dirigem uns aos outros, elegem as mulheres como interlocutoras. Assim, mesmo os confrontos entre homens aparecem como ataques dirigidos às mulheres, como se a conversão de uma "fala ruim" ou “fofoca” em ato público e ritual dependesse da inclusão das mulheres no circuito. As mulheres quando cantam também tomam outras mulheres como destinatárias de seus cantos, e não parecem se dirigir aos homens.

Faremos uma apresentação dos cantos selecionados agrupando-os a partir de dois grandes temas, a feitiçaria e a afinidade, que podem, eventualmente, ser atravessados por um terceiro: a chefia. Essas aproximações temáticas são arbitrárias, já que, como veremos, esses temas podem se interpenetrar e se aproximar em algumas das canções, mas essa parece ser uma estratégia útil para evidenciar alguns "centros de atração semântica" das composições. Começaremos explorando a "vizinhança" do canto anterior, um dos grandes motes do kuambü: a feitiçaria.

2.

Ugeingoingo kaha ukaengoingo kaha ukitsipügü inde

Ugeingoingo kaha ukaengoingo kaha ukitsipügü inde

Ekü heke tuepügü ekü heke isoinjü

Tohoingoingo büna ukaengoingo büna ukitsipügü inde

Ekü heke isoinjü ekü heke tuepügü

Tohoingoingo büna ukaengoingo büna ukitsipügü inde

Ugeingoingo kaha ukaengoingo kaha ukitsipügü inde

Ugeingoingo kaha ukaengoingo kaha ukitsipügü inde
Serei eu, sobre mim é que recairá a culpa, quando morrermos aqui

Serei eu, sobre mim é que recairá a culpa, quando morrermos aqui

"Fulano o matou, fulano o enfeitiçou"

Logo recairá uma acusação de morte sobre mim, quando morrermos aqui

"Fulano o matou, fulano o enfeitiçou"

Logo recairá uma acusação de morte sobre mim, quando morrermos aqui

Serei eu, sobre mim é que recairá a culpa, quando morrermos aqui

Serei eu, sobre mim é que recairá a culpa, quando morrermos aqui

Este canto é uma costura, feito em sua defesa, por um homem acusado de feitiçaria. O cantor diz publicamente que é acusado, o que no contexto do kuambü é um modo de colocar a acusação em dúvida. Por que um feiticeiro de verdade se exporia em público? Costurando sobre si mesmo, o acusado muda seu lugar na relação, se colocando como vitima de acusações infundadas e espera, com isso, que as acusações cessem, ou se voltem à outra pessoa.

Além de atacar feiticeiros (reais ou potenciais) ou defender a si mesmo, outros cantos sobre o tema podem assumir uma forma de agressão a alguma vítima de feitiçaria:

3.

Apungu apungu itaĩ

Eitsilü eitsilü itã̃

Itaõni
Você morreu, você morreu, mulher Você faleceu, você faleceu, mulher

Mulheres 
Ingikeha ingikeka akitingope ake apungu itaó

Ingikeha ingikeha eingunkgingope akela apungu itaõ

Undena tajoko atani

Unde isike atani

Apungu apungu itaó

Eitsilü eitsilü itaó
Veja só, veja só, sem aquele de quem você gostava você morreu, mulher

Veja só, veja só, sem aquele em quem você pensava você morreu, mulher Onde estaria então a taturana? Onde estaria então a tocandira? Você morreu, você morreu, mulher Você faleceu, você faleceu, mulher

Nesse canto, um homem, o mais velho de quatro irmãos, apassarinhou uma mulher. Seu irmão mais novo estava noivo da filha de seu tio materno e, anos depois, quando o casamento aconteceu, a mulher o deixou dizendo: "Uakitingo ila kenguhitsani, uingugu akitingo", "Eu ainda vou procurar alguém de quem eu goste, alguém de quem meus olhos gostem" (repare no embutimento enunciativo de uma fala atribuída à mulher na composição). Após deixá-lo, a moça morreu. Quando seu pai já havia saído do luto, houve kuambü e o irmão mais velho do noivo abandonado compôs esse canto, reprovando a atitude da mulher (sua prima) e sugerindo que sua morte havia sido o troco dado por um feiticeiro, que aparece aqui referido como uma taturana ou uma formiga tocandira (dois insetos que causam dor).

A história desse canto dá pistas da capacidade do kuambü produzir efeitos na vida social para além do contexto ritual. Logo após a morte da moça, diziam que o irmão mais velho de seu ex-marido a havia matado com feitiço, mas não houve acusação pública. Porém, depois de ouvi-lo cantar o pai da jovem teve certeza de que aquele era o feiticeiro. Pagou outra pessoa para vingá-lo e o cantor foi executado um dia depois da festa. Este canto também pode ser visto como um comentário sobre a proximidade entre feitiçaria e relações amorosas ou de afinidade que, conforme apontamos, são o mote de muitas composições.

4.

Tüna otoinjü kilüi itaõ
Tüna otolükijü kilüi itaõ
Uointsa tale igei itaó kilü egei
Uihitsa tale igei itaõ kilü egei
Tünohandühügü heketsü itaô kilü egei
Tetijinkgitsügü heketsü itaõ kilü egei
Tüna otoinjü kilüi itaõ
Tüna otolükijü kilüi itaõ

Tüna otoinjü kilüi itaó

Tüna otolükijü kilüi itaō

Uointsa tale igei itao kilu egei

Uibitsa tale igei itaó kilü egei

Tetijinkgitsügü heketsü itaõ kilü egei

Tüna otoinjü kilüi itaó

Iuna otolükijü kilüi itaō
Como você disse estar enfeitiçada, mulher? Como você diz que alguém vai te matar, mulher?

“Estou amarrada!", é o que disse uma mulher “Mexeram comigo!", é o que disse uma mulher Sobre sua gravidez, é o que disse uma mulher Sobre seu aborto, é o que disse uma mulher Como você disse estar enfeitiçada, mulher? Como você diz que alguém vai te matar, mulher?

Uma mulher engravidou de seu namorado, mas fez um aborto. Com medo da situação, ela teria acusado o namorado de enfeitiçá-la para provocar o aborto, o que, segundo quem me narrou os eventos, seria mentira. O homem, em sua composição apassarinha a mulher, ao mesmo tempo citando o que teriam sido suas palavras, e revelando aos demais o que teria acontecido de fato. Novamente há uma inversão da relação prévia entre emissor e destinatário: aquele que era acusado, torna-se aqui vítima e acusador (não de feitiçaria, neste caso, mas de uma mentira). 
Angolo beke nikale itaõ kilü egei

Imütongo heke nikale itaó kilü egei

Itaôni

Unhoi heitse itaõ kilü egei

Ukaengaha eitse itaô kilü egei

Unhoi heitse itaõ kilü egei

Eititegomitiha uheke itaó kilü egei

Atabitsegomitiha uheke itaó kilü egei

Angolo beke nikale itaó kilü egei

Imütongo heke nikale itaó kilü egei
Será verdade o que disse uma mulher?

Será que uma mulher disse isso na cara dele?

Mulheres

"Seja meu marido", é o que disse uma mulher

"Fique junto a mim", é o que disse uma mulher

"Seja meu marido", é o que disse uma mulher

"Para que eu possa fazer sua rede", é o que disse uma mulher

"Para que eu possa fazer sua esteira", é o que disse uma mulher

Será verdade o que disse uma mulher?

Será que uma mulher disse isso na cara dele?

Este canto é direcionado por um pai a uma mulher que havia pedido secretamente seu filho em casamento, mas o homem desaprovou a união. Mais um canto representativo de um conjunto de peças que relatam conflitos em torno de relações amorosas e de afinidade: namoros terminados, traições, noivados e casamentos fracassados, desrespeito entre sogros/as e genros/noras. Mesmo as relações de afinidade intergeracional, de extremo respeito, podem aparecer como objeto de conflito, como no caso de um canto em que uma sogra se queixa indiretamente das coisas que sua nora havia lhe dito:

6.

Ületsügü büngü etubijü hüngüti uhokondikümbeke

Ületsügü hüngü etuhijü hüngüti uhokondikümbeke

Itaõni

Aiha aih a tühokonditi tiha uanügü iheke Aiha aiha tunkguliti tiha uanügü iheke Ületsügü büngü etubijü hüngüti uhokondikümbeke Ületsügü büngü etuhijü hüngüti uhokondikümbeke
Não foi só uma vez, não começou agora, a me caluniar

Não foi só uma vez, não começou agora, a me caluniar Mulheres

Chega, chega, ela já me caluniou Chega, chega, ela já falou mal de mim

Não foi só uma vez, não começou agora, a me caluniar

Não foi só uma vez, não começou agora, a me caluniar

Já o canto a seguir foi composto pela esposa de um homem para uma de suas amantes:

7.

Engikondetomi tsüha iheke
Atautegomi tsüha iheke
Itaõni
Inhaheke tsüha agatohondeke itaó
Inhaheke tsüha etigondeke tsüha itaó
Engikondetomi tsüha iheke
Atautegomi tsüha iheke
Itaóni

Engikondetomi tsüha iheke

Atautegomi tsüha iheke

Itaoni
Para que ele lhe dê coisas Para que ele lhe dê cestos Mulheres Se amigue logo a ele, mulher Junte logo sua rede à dele, mulher Para que ele lhe faça coisas Para que ele lhe faça cestos Mulheres 
A cantora provoca a amante de seu marido a casar-se logo com ele (é este o sentido de "amigar-se" e "juntar sua rede"), insinuando que seu interesse seria ter um marido para fazer objetos que lhe faziam falta, como cestos. O destinatário explícito é uma mulher, mas é interessante notar que aqui também o coletivo de mulheres aparece como um "destinatário genérico" do canto.

Apesar de menos frequentes, as relações intercomunitárias também podem aparecer no kuambü, associadas a relações de afinidade:

8.

Tekinbü kitoho tisugei
Katutolo kitoho tisugei
Inkeha tisetu tekinhü
Inkeha tisitsitsü tekinbü
Tolo nhengeni ekitoho
Kajü nhengeni ekitoho
Katutolo kitoho tisugei
Tekinhü kitoho tisugei

Tekinhü kitoho tisugei

Inkeha tisetu tekinhü

Inkeha tisitsitsü tekinhü

Tolo nhengeni ekitoho

Katutolo kitoho tisugei

Tekinhu kitoho tisugei
Estrangeiros falam de nós Todos falam de nós Veja nossa aldeia, estrangeiro

Veja nosso lugar, estrangeiro Para você dizer "são comedores de aves" Para você dizer "são comedores de macacos" Todos falam de nós Estrangeiros falam de nós

Este canto foi composto para um homem kuikuro que era famoso por dizer que nunca iria na aldeia dos Kalapalo para não ter que comer aves e macaco (a comida mais valorizada pelos alto-xinguanos é o peixe, mas a antiga aldeia kalapalo ficava longe do rio). Contudo, este kuikuro acabou se casando com uma mulher kalapalo e foi morar com ela, tornando-se destinatário de um tolotelü. Vale notar que aqui o destinatário (nos versos 3 e 4) não são as mulheres, nem é referido como um semelhante, mas como um estrangeiro (tekinhü).

Como já apontamos, para além dos temas da feitiçaria e das relações amorosas e de afinidade e, muitas vezes, relacionado a ambos, outro tema bastante recorrente nos cantos é a chefia, algo pouco mencionado nos trabalhos sobre o kuambü. Fizemos, então, uma seleção de cantos que tratam dessa temática, conforme apresentados a seguir.

9.

Ukuge toho utetani

Anetaõ tinbügüti utetani

Uãbüngü kana gitse euege uagingo

Ukuge toho mbogitsügü umbege gitse enege uagingo

Anetaõ toho mbogitsügü umbege gitse euege uagingo

Abütü tubutila tisuge uagingo

Ukuge toho utetani

Anetaõ tinhügüti utetani
"Ser chamado de gente, me deixem ser" "Ser chamado de chefe, me deixem ser"

Ainda que você o seja, meu semelhante Em vão você nasceu de alguém chamado de gente, meu semelhante Em vão você nasceu de alguém chamado de chefe, meu semelhante Nós não somos reconhecidos, meu semelhante "Ser chamado de gente, me deixem ser" "Ser chamado de chefe, me deixem ser" 
Este é o canto de um chefe (anetü) para seu primo cruzado, que também era chefe, mas não era reconhecido como tal. Nas duas primeiras linhas, o cantor desvaloriza o desejo de seu primo pela chefia, argumentando na bifurcação (linhas 3-6) que, ainda que ele tenha ascendência de chefes, sua condição de chefe não será reconhecida. Nesse trecho há a publicização de uma disputa sutil entre os chefes. O cantor chama seu primo de uagingo, "meu semelhante", reconhecendo seu parentesco com ele e a condição de chefe de ambos. Contudo, na última linha, quando o cantor diz "Nós não somos reconhecidos, meu semelhante", ele utiliza uma forma exclusiva da segunda pessoa do plural (tisuge), implicando que o destinatário não faz parte desse coletivo de verdadeiros chefes que, apesar de sua ascendência, não são reconhecidos como tais. Este canto tem uma dupla mensagem: é uma provocação ao primo que quer ser chefe, que desvaloriza seu desejo e questiona seu real pertencimento ao coletivo dos verdadeiros chefes; mas é também uma crítica à desvalorização dos chefes pelos seus seguidores, uma queixa frequente de todo anetü.

10.

Ketego ketego isakandohona
Ketego ketego inhüngatahonga
Ülepene gehale isakanümingo
Tuãtuhugu ake isakanümingo
Tügipondogu ake isakanümingo
Ketego ketego isakandohona
Ketego ketego inbüngatahonga

Não vamos, não vamos, para onde ele se senta Não vamos, não vamos, para a frente de sua casa Depois disso ele ainda se sentará Com sua borduna, ele se sentará Com seu chapéu, ele se sentará

Não vamos, não vamos, para onde ele se senta Não vamos, não vamos, para a frente de sua casa

Este canto é uma provocação a um chefe, considerado dono da aldeia, que havia ficado com raiva porque seu filho estava doente. Com isso, ele passou a carregar consigo uma borduna, dizendo em público que ia matar seus irmãos e seus primos. Seu filho melhorou e, tempos depois, ele chefiou seu pessoal quando foram a um Quarup ${ }^{15}$, carregando nas mãos arco, flecha e borduna ${ }^{16}$. Algum tempo depois, quando sua raiva já tinha passado, ele voltou a atuar como chefe, discursando no centro da aldeia exortando as pessoas a ficarem calmas e boas. Seu primo cruzado, que ele havia acusado de enfeitiçar seu filho, não gostou de vê-lo agindo como chefe depois do acontecido e, quando dançaram kuambü, ele criticou o comportamento agressivo do chefe. Os primeiros dois versos recomendam que as pessoas evitem passar na frente de sua casa, pois poderiam ser mortos. Os versos seguintes falam sobre o chefe "se sentar", que é sinônimo de "chefiar": os chefes de um grupo, quando levam seu pessoal a uma festa, são conduzidos pelos chefes anfitriões a se sentar sobre bancos de madeira, onde ficam nos momentos de recepção e despedida, e durante as performances rituais. Chefes devem ser pessoas calmas e de atuação pacificadora, devem se adequar ao modelo da ética alto-xinguana e não podem exibir agressividade pública. Contrastando o comportamento do chefe durante a doença de seu filho com seu comportamento posterior, o cantor questiona que uma pessoa agressiva possa "se sentar", portando publicamente seus instrumentos de chefia (como o chapéu de couro de onça e a borduna - posteriormente substi-

15 Ritual mortuário em memória de pessoas importantes, como chefes e seus parentes (Guerreiro $2015 \mathrm{a}$ ).

16 Dizem que antigamente os chefes andavam o tempo todo armados com um arco, para discursarem para as pessoas. 
tuída por arcos e, mais recentemente, por espingardas), que devem ser utilizados apenas para proferir discursos rituais.

11.

Ingitüe etepegane

Itsatüe etepegane

Itaõni

Ugihongope tale ugei itaó kilü egei

Anatugohope tale ugei itaó kilü egei

Ingitüe etepegane

Itsatüe etepegane
Vejam uma falsidade

Ouçam uma falsidade

Mulheres

"Eu fui daquelas sobre o banco", é o que disse uma mulher

"Eu fui uma queridinha", é o que disse uma mulher

Vejam uma falsidade

Ouçam uma falsidade

Um homem compôs este canto para sua prima cruzada que, quando jovem, era uma mulher bonita e, ao envelhecer, gostava de dizer às pessoas que havia chefiado seu povo em festas (tinha ido "sobre o banco", isto é, se sentado nos bancos de chefe), e que ela sempre havia agradado sua mãe no passado. Como ela nunca havia sido chefe de fato, seu primo decidiu expor sua mentira em público.

12.

\author{
Anetü toho engimbükike uoho \\ Tongisa toho engimbükike uoho \\ Itaôni \\ Euege leha eitsatomi ülei \\ Anetü toho unkgupügü hüngü \\ Tongisa toho unkgupügü hüngü \\ Anetü toho engimbükike uoho \\ Tongisa toho engimbükike uoho
}

Acabe com quem é chamado de chefe, por favor Acabe com quem é chamado de tongisa, por favor

Mulheres

Para que você fique em seu lugar

Que não é filho de alguém chamado de chefe

Que não é filho de alguém chamado de líder

Acabe com quem é chamado de chefe, por favor

Acabe com quem é chamado de tongisa, por favor

Este canto é um bom exemplo da mistura das temáticas da feitiçaria e da chefia. Foi composto para um feiticeiro que já havia matado muitos chefes. $\mathrm{O}$ cantor ironiza a situação de duas maneiras: pede para acabar com os chefes (enfatizando por meio do uso do termo tongisa, vocativo para "chefe"), mas ao mesmo tempo em que sugere ao feiticeiro que tome seu lugar, destaca que ele não tem ascendência nobre para isso.

Uma última temática que marca o kuambü são algumas relações com os brancos:

13.

\author{
Ülegote gitse utsünginda gitse \\ Ihatote gitse utsünginda gitse \\ Itaôni \\ Ati aketsange Eló enta ina \\ Ati aketsange Eló enta ina \\ Ülegote gitse utsünginda gitse \\ Ihatote gitse utsünginda gitse \\ Itaõni
}

Que isso vá acontecer, está me preocupando Que ele vá aparecer, isso está me preocupando

Mulheres

"Veja lá, Elõ está vindo pra cá!"

"Veja lá, Elô está vindo pra cá!"

Que isso vá acontecer, está me preocupando

Que ele vá aparecer, isso está me preocupando

Mulheres 
No canto acima, uma mulher chefe explicita sua preocupação com as fofocas que circulam sempre que um de seus amigos não indígenas vem visitar sua família. A cada visita, ele lhe trazia muitas miçangas, o que deixava as mulheres das outras casas com inveja, na expectativa de que ela distribuísse tudo o que ganhasse. Em seu canto direcionado ao coletivo de mulheres, ela compartilha a angústia de ser colocada em uma posição desconfortável por causa de suas relações com os brancos. Ainda, ao expor em público as fofocas que sempre correm quando seu amigo a visita, a cantora espera que suas adversárias se envergonhem e não façam rumores a seu respeito.

14.

Tü hekena ubinhondengalüingo?

Tü bekena ubinhondengalüingo, itẫ?

Tü hekena uhinhondengalüingo?

Itaôni

Togonha hekeha ugepulenümingo tühügiki igei

Tuminkgu hekeha ugepulenümingo tühügiki

igei

Tü hekena ubinhondengalüingo itaõ?
Quem será que vai me proteger?

Quem será que vai me proteger, mulher?

Quem será que vai me proteger?

Mulheres

Noronha é quem me queimará com a pólvora

de sua arma

Domingo é quem me queimará com a pólvora

de sua arma

Quem será que vai me proteger, mulher?

Neste canto, um homem expõe sua preocupação de ser morto por dois brancos, antigos funcionários da Expedição Brasil Central que moravam perto da aldeia onde os Kalapalo viviam quando o canto foi composto. Apesar da proximidade e do contato com os brancos ter motivado os Kalapalo a se estabelecerem perto de seu acampamento, o cantor não esconde sua preocupação com a possibilidade de tal proximidade revelar uma face violenta.

\section{Perto demais}

Apesar da liberdade de invenção e do frequente encaixe de falas dos outros nas composições, o kuambü tem um estilo claro, tanto em termos de sua forma poética quanto de seu campo semântico. Assim como em outros gêneros verbais xinguanos, vemos a recorrência do paralelismo e de fórmulas. O paralelismo é uma marca das artes verbais (Franchetto 2000,2003) e pode aparecer como a repetição estrita de versos, a repetição de versos com pequenas variações e a repetição alternada de blocos de versos.

Junto com o paralelismo, algumas expressões formulaicas são peças-chave tanto para caracterizar um "estilo" (o enquadramento epistêmico de relações ou interações) quanto para a dinâmica criativa dos cantos. Como as mulheres são fontes centrais de assuntos dos cantos, muitos versos são compostos por uma fala citada seguida da fórmula itaõ kilü egei, "é o que disse uma mulher" (como nos cantos 4, 5 e 11). Outros versos são iniciados pela formulação angolo nikale, "será verdade", acompanhada da descrição de um evento, situando o canto no campo dos rumores (como no canto 5 dos nossos exemplos, havendo outros que ficaram de fora da seleção). Ainda, a descrição dos efeitos da ação de outros sobre o 
cantor e que se tornam motivo de sua composição são seguidas da fórmula uanügü eheke, "você me fez assim" ou "você me deixou assim" (canto 6). Há ainda termos recorrentes para se falar dos feiticeiros, marcados como não humanos (onça, taturana e formiga tocandira), evitando-se referências diretas.

Por fim, alguns cantos trazem partículas epistêmicas recorrentes, como gitse, nika e tüha. Gitse é descrito por Basso como uma "partícula afetiva", usada para expressar "unfortunate circumstances" (Basso [s.d.]:371), tendo o sentido de "poorly" ou "incomplete" (Basso 2009). Segundo Franchetto (2000), gitse seria uma partícula de desvalorização. Ela é bastante frequente nos discursos de chefes kalapalo quando estes falam sobre o presente, evidenciando como o mundo atual é relativamente infeliz e imperfeito quando comparado ao passado (Guerreiro 2015b). Nika, por sua vez, é um epistêmico usado em interrogativas que indica dúvida e busca confirmação (Basso [s.d.]:380). O epistêmico tüha também indica dúvidas por parte do falante, mas em construções afirmativas, deixando explícito que o enunciador não tem conhecimento em primeira mão dos fatos narrados (Rabello 2013). Ou seja, os marcadores epistêmicos identificados nessa pequena amostra de cantos evidenciam que os objetos das composições pertencem ao mundo do desagradável, do duvidoso e do incerto - em suma, ao mundo oculto dos rumores, tornados públicos no contexto ritual.

Quanto ao campo semântico, como já dissemos, as canções parecem girar em torno de alguns temas básicos, como feitiçaria, afinidade, chefia e mesmo os brancos. Longe de formar subgêneros no kuambü, é comum que esses temas se sobreponham. Se não o fazem em um canto, podem se conectar nas interpretações sobre as peças e as memórias das situações que suscitaram as composições. É como se o ritual revelasse que as relações evocadas por tais temas (o amor, a violência, o sexo, o casamento, o poder), apesar de parecerem pertencer a dimensões distintas da vida social, são terrivelmente próximas, a ponto de se converterem umas nas outras, como se fossem transformações de um mesmo problema de fundo.

Com efeito, pode-se pensar esses grandes temas como referências às formas de "alteridade interna" ao grupo local. Os chefes são vistos como "pais" e protetores de uma aldeia, mas as marcas da alteridade se fazem visíveis quando atuam em público, com a prerrogativa do uso de adornos de animais predadores e do porte de armas (arco, flecha, borduna, espingarda), que os marcam como inimigos em potencial. A feitiçaria, como demonstra Vanzolini (2015), ocorre nos limites do parentesco, ali onde a proximidade pode despertar inveja, ciúmes e mostrar que um parente era (ou sempre pode vir a ser), no fundo, um inimigo. E a diferença de gênero, por sua vez, se é o que une casais em unidades domésticas e famílias em aldeias, também é uma fonte inesgotável de tensões entre homens e mulheres, e entre afins ligados pelo casamento de seus filhos, filhas, irmãos e irmãs. Mesmo os brancos, quando aparecem nesses cantos, são pessoas muito próximas dos compositores.

O kuambü parece jogar com a ambiguidade aparentemente irredutível dessas relações, que estão sempre na fronteira da identidade com a alteridade, do eu e do outro, do parente e do inimigo. A alteridade, que é o ponto de partida de produção da vida social, pode ser domesticada, mantida sob controle, mas nunca completamente apagada. Ela será sempre contraefetuada de alguma forma (Viveiros de Castro 2002). 
Este ponto sugere conexões entre o kuambü e outros rituais de origem aquática - o unduhe propriamente dito e o kagutu. O primeiro é uma festa que possui duas versões: uma "festa de peixes" (possuída/ performada pelos Kalapalo) e uma "festa de cobras" (que seria executada pelos povos de origem arawak). A versão Kalapalo foi aprendida junto aos peixes, e seu repertório musical inclui cantos que tratam tanto de peixes como também de outros bichos, como aves e animais terrestres. Os homens, paramentados com saiotes de palhas e adornos de folhas, dançam ao som desses cantos, que representam os animais, tais como feitos pelos peixes. As mulheres acompanham os homens nas danças e, na maior parte do tempo, não é marcada nenhuma distinção entre chefes e não chefes, e as relações entre homens e mulheres não são marcadas por antagonismo (ao contrário, são marcadas por jocosidade nos cantos de alguns animais, como a cotia). Mas se uma oposição entre homens e mulheres não é marcada nas performances do unduhe propriamente dito, ela aparece quando, durante a festa, as flautas kagutu são tocadas. Esse conjunto de flautas interditas às mulheres possui um ritual próprio, mas é também executado junto com os cantos do unduhe, sendo considerado akongo ("que vai junto", "acompanhamento") dessa festa. Assim, toda vez que se realiza a festa unduhe as flautas devem ser tocadas, o que ocorre, em geral, dentro da casa dos homens, evitando que sejam vistas pelas mulheres, que dançam no centro da aldeia.

Uma versão "simplificada" do unduhe (com um repertório restrito) é executada frequentemente por prazer e, como parece ser comum, para comemorar a conclusão de algum trabalho coletivo (como a abertura de uma aldeia, de uma roça ou a construção de uma casa) ou durante eventos esportivos (como torneios de futebol) e reuniões envolvendo distintos povos da região ${ }^{17}$. Nesses momentos, é comum que mulheres de um povo dancem junto a homens de outro povo. Os Kalapalo também relatam que povos como os Kawaiweté e Kĩsêdjê realizam suas próprias versões dessa festa. A versão "completa" do unduhe, quando seu repertório completo de cantos é executado ${ }^{18}$, ocorre no período das chuvas, momento das festas restritas ao grupo local. Essa é também a festa que marca as atividades vespertinas do uluki (mais conhecido por moitará, seu nome em kamayurá), uma festa em que duas aldeias de povos distintos se reúnem para trocar seus objetos e dançar (Novo 2018). É a única festa interaldeias que ocorre no auge do período de chuvas e na qual anfitriões e hóspedes tratam-se como amigos e parentes, o que se evidencia com os visitantes dormindo em alguma casa do círculo de casas da aldeia anfitriã, com visitantes e anfitriões comendo alimentos preparados conjuntamente e com as mulheres visitantes dançando junto com os homens anfitriões e vice-versa. O uluki cria a imagem de que duas aldeias de povos distintos podem se ver, temporariamente, como consanguíneos e corresidentes, e o unduhe é um dos pilares dessa construção relacional (Novo \& Guerreiro 2020).

$\mathrm{O}$ ritual do kagutu propriamente dito é feito quase sempre à noite, com mulheres e crianças fechadas em casa para que as flautas possam percorrer a aldeia (mas o ritual também pode ocorrer durante o dia, a depender do que motivou sua execução). O kagutu divide a aldeia em dois grupos hierarquizados pelo sexo, com uma relação de agressividade dos homens direcionada às mulheres. Por ser um acompanhamento do unduhe, o kagutu também é realizado durante o uluki, quando os homens do grupo visitante tocam as flautas dos anfitrióes.

17 Nesses eventos, geralmente as flautas kagutu não são tocadas.

18 Sobre a diferença entre as versões "completa” e "simplificada", ver Novo (2018). 
Unduhe e kagutu geram imagens alternativas e complementares do grupo local: um grupo de pessoas que preparam alimentos, comem, dançam e se alegram juntas, de um lado; mas que podem ser divididas em dois grupos em uma relação assimétrica - homens e mulheres -, de outro. É como se o kuambü completasse o quadro, revelando aquilo que, apesar de atravessar essas duas perspectivas da socialidade local, permanece oculto tanto no cotidiano do parentesco (ao qual pertencem a afinidade e a feitiçaria), quanto na excepcionalidade dos grandes rituais (domínio por excelência da chefia).

Também é preciso investigar mais a fundo as relações do kuambü com o tolo feminino. Esses cantos são descritos como "traduções", pelas mulheres, das melodias das flautas masculinas (Franchetto 2018:27). Como já discutido por Franchetto, são cantos que falam de "falta, fuga, ciúmes ou inveja, provocação" (Ibid:31), descritos pela autora como pequenos poemas nos quais encontram-se "pinceladas ou imagens mentais de situações excitantes, relações clandestinas e vitais, sentimentos, que atravessam a vida das mulheres (e dos homens), por vozes femininas e, como seu reflexo sobredeterminado, também por vozes masculinas" (Ibid, loc. cit.). Estes cantos também são marcados pela "recursão de falas citadas", emolduradas pela fórmula "uhisü kilü uheke (hegei), 'eu disse para o meu jovem irmão/ primo/amado" (Ibid:32) ${ }^{19}$. Vale notar a semelhança entre essa construção e a fórmula itaõ kilü egei, "é o que uma mulher disse / é o que as mulheres disseram", presente no kuambü, que ao trasladar a perspectiva da enunciação das mulheres aos homens, produz uma desvalorização da fala feminina. Com efeito, ao discutir um canto kuambü dos Kuikuro em que um homem critica a circulação de fofocas feita por "vaginas" e "clitóris", Franchetto demonstra como "a fala feminina é radicalmente naturalizada: são as vaginas e os clitóris que contam" (Franchetto 1997:62).

O tolo feminino transforma o ritual das flautas proibidas revelando que os instrumentos dos homens guardam uma perspectiva feminina, enquanto talvez seja possível dizer que o kuambü transforma o undube revelando que a socialidade idealizada do grupo local como um grupo de parentes guarda uma perspectiva afim/inimiga. Quanto às relações de gênero em particular, é como se o tolo fizesse um contraponto à hierarquia entre homens e mulheres, levando as mulheres ao centro da aldeia e colocando em primeiro plano as relações intensamente afetivas entre eles (nos cantos de amor, sexo, ciúme), lado a lado com seus antagonismos (nos cantos de provocação aos homens) ${ }^{20}$. Num certo sentido, o kuambü também joga com transformações das relações de gênero, pois ao mesmo tempo faz os homens cantarem publicamente sobre rumores (ritualizando a "fala do quintal", como a chama Gregor [1977], atribuída às mulheres), assim como permite às mulheres falarem/cantarem publicamente sobre política. Ao invés de explicitar uma separação assimétrica entre os gêneros, como no kagutu, ou buscar sua conjunção, como no unduhe, os cantos de kuambü enfatizam a "síntese disjuntiva" efetuada por suas relações, explicitando conflitos entre afins de sexo oposto (homens e mulheres), afins efetivos de mesmo sexo (sogro/genro, sogra/nora) ou afins potenciais (primos cruzados) de ambos os sexos. Com esse

19 Entre os Kalapalo também é comum encontrar uma variação dessa fórmula: uhisü kilü uheke, "meu jovem irmão/primo/amado disse para mim".

20 Sob esse aspecto, tolo e jamugikumalu (Jamurikumã) parecem questionar a hierarquia androcêntrica a partir de duas perspectivas alternativas e complementares: enquanto o tolo põe em evidência os afetos e a sexualidade entre homens e mulheres, apontando para a socialidade do parentesco, o jamugikumalu destaca a possibilidade de emergência de uma socialidade ritual hiperfeminina, da qual os homens podem estar (como já estiveram no passado mítico) excluídos. 
movimento, o kuambü recoloca a afinidade do grupo local em evidência, e talvez por isso atraia para seu universo outros tipos de afins potenciais/inimigos, como os chefes e os brancos.

Por fim, cabe perguntar sobre aspectos pragmáticos e relacionais do ritual. Como as composições extraem seu sentido de contextos sociais apenas indicados nelas, mas que são facilmente desdobrados pelos ouvintes ${ }^{21}$ ? Que tipo de efeitos isso gera, e como são produzidos? Ao menos alguns cantos analisados deixam claro que cantar pode ter efeitos extrarrituais: em um caso, o cantor foi executado (canto 3); em outro, espera-se que o chefe criticado reflita sobre seu comportamento e se envergonhe (canto 10); em um terceiro, o canto pretende cessar a fofoca antecipando-a, também pela vergonha das destinatárias (canto 13). A recusa pelos cantores de executar suas composições fora do contexto ritual, ou de reproduzir cantos de pessoas vivas, também é um indicador de que o ato de cantar pode ter sérios efeitos na vida cotidiana.

Uma perspectiva pragmática e relacional da ação ritual, tal como proposta por Houseman e Severi, pode nos ajudar a pensar. Que tal perspectiva seja pragmática significa que os rituais devem ser considerados como contextos interativos construídos a partir de modos de relacionamento da vida cotidiana e produzindo efeitos sobre ela. E que ela seja relacional implica em dar atenção ao modo como o ritual é criado enquanto um contexto com uma lógica própria, que (geralmente) combina modos de interação que, em outros contextos, são tidos como contraditórios e incompatíveis (Houseman \& Severi 1998). Adicionalmente, um dos argumentos de Berthomé e Houseman que sugere uma conexão com o contexto xinguano é a centralidade das emoções nos rituais. Segundo eles, as emoções são as qualidades sensíveis das relações, e é por meio delas que os rituais ao mesmo tempo criam configurações interativas próprias e produzem efeitos sobre outras relações sociais (Berthomé \& Houseman 2010).

Com efeito, um idioma das emoções marca muito do que os Kalapalo dizem sobre sua vida ritual, e também sobre seu ethos: vergonha, raiva, alegria, tristeza, são emoções associadas a diversas relações sociais. Mas qual o propósito de fazer uma festa que, se por um lado é divertida, por outro também é tida como "feia" ou "dolorosa"? Uma de nossas interlocutoras dizia que "kuambü é muito doloroso. As pessoas nos enviam tolo, e nós sentimos com isso. No kuambü as pessoas se atacam”. Outro interlocutor, comentando os cantos que traduzíamos, me disse: "Se alguém cantar sobre você, você vai sentir com isso. Se a pessoa falar de alguma coisa que você fez, alguma coisa que você falou, você vai ficar com vergonha. Às vezes as pessoas cantam mentiras, e alguém pode ficar com raiva e responder. Faz tempo que não fazemos essa festa, porque da última vez quase deu briga de verdade". Perguntando como as pessoas ficavam depois da festa, esse mesmo interlocutor disse: "Durante a festa pode cantar qualquer coisa. As pessoas que ouvem um canto ficam pensando, pensando, e depois da festa fica tudo bem, ninguém briga mais".

Os cantos parecem ter duas audiências distintas, que se afetam por ele de modos diferentes. $\mathrm{O}$ destinatário, ao ser criticado em público, pode sentir vergonha ou dor, e esta pode se converter em raiva;

21 É notável como as pessoas conseguem reconstruir os contextos de composição da maioria das canções ao ouvi-las. É tentador pensar essas canções como pequenas "crônicas" da vida social e que funcionam como uma espécie de "pílulas de memória". Seguindo uma sugestão de Carlos Fausto (comunicação pessoal, julho de 2019), talvez os cantos kuambü estejam entre o registro histórico e a condensação ritual (Houseman \& Severi 1998): suas formas convencionalizadas podem apontar tanto para situações arquetípicas de composição quanto para situações concretas. 
já a audiência ampla, diante das performances caricaturais dos cantores, pode muito bem achar graça (rir de um alguém retratado como sovina, de quem se comporta como um agressor em potencial, de um pai orgulhoso que não permitiu o casamento de seu filho ou filha). Isso parece permitir inversões das relações sociais previamente existentes: quem tinha vergonha, estava calado e era ofendido, no ritual perde a vergonha, canta e pode ofender; quem ouvia fofocas e acusações como verdadeiras, é convidado a rir delas, como se não fossem plausíveis; e quem recebe um canto-mensagem como acusação, passa da posição de ofensor a ofendido, e a dor e a vergonh a provocados pelo canto podem mudar o seu comportamento.

É como se a imagem da costura que marca o ato da composição também remetesse a alguma capacidade desejada de "sutura" do tecido social. Exibindo os cortes desse tecido, torna-se possível costurá-lo, o que o kuambü faz criando um contexto interativo no qual alegria e feiura, riso e dor, desinibição e vergonha, fala/ação privada e fala/ação pública, se sobrepõem. A produção de afetos específicos por essa configuração interativa, por sua vez, permite a reconfiguração de um conjunto de relações sociais. Não se trata nem de "exprimir" a socialidade da vida aldeã nem de "restaurá-la", mas de oferecer meios para sua reinvenção.

Isso nos remete de volta, por fim, à associação do kuambü à política pelos alto-xinguanos. Ele parece incidir sobre as relações sociais mobilizando falas, ações e afetos que constituem uma "micropolítica”. Segundo Deleuze e Guattari, esta seria uma política molecular, que se desenrola em um campo de intensidades infinitesimais formado por "crenças e desejos" que compõem o "fundo da sociedade" (Deleuze \& Guattari 1996: 98) - "uma micropolítica da percepção, da afecção, da conversa, etc." (Ibid:99). Diferentemente dos rituais multicomunitários, que estabilizam, ainda que por um tempo limitado, as diferenças entre aliados e adversários, anfitriões e estrangeiros, consanguíneos e afins, o kuambü revela como "intensidades infinitesimais" - o ciúme, a inveja, a raiva, a dor -, não param de agitar e remanejar os segmentos da macropolítica. Não estamos aqui no plano dos debates sobre o poder e a chefia, que tendem a ser o pivô dos trabalhos sobre política na etnologia amazônica, mas no plano das pequenas coisas que podem juntar ou separar as pessoas: trocas, amores, respeito, riso, dor, vergonha, raiva. Pode ser produtivo nos aproximarmos dessa linguagem se quisermos entender melhor do que trata a criatividade ritual xinguana. Expondo fissuras e tentando, nem sempre com sucesso, suturá-las, o kuambü reflete sobre uma dialética da qual depende a produção da vida: o parentesco se produz contra alteridades perigosas, procurando se distanciar delas, mas parece sempre acabar contraproduzindo mais alteridade. Esse "perpétuo desequilíbrio", no fim das contas, não permite que esse movimento termine nunca. Talvez ele pudesse acontecer sem o kuambü. Mas por que não cantar?

\section{Antonio Guerreiro é doutor pelo PPGAS/UnB e professor do Departamento de Antropologia da UNICAMP.}

Marina Pereira Novo épós-doutoranda no Departamento de Antropologia da UNICAMP. 


\section{REFERÊNCIAS BIBLIOGRÁFICAS}

BARCELOS NETO, Aristóteles. 2008. Apapaatai: Rituais de Máscaras no Alto Xingu. São Paulo: EDUSP/FAPESP.

BARROS, Edir Pina de. 2003. Os filhos do sol. História e Cosmologia na Organização Social de um Povo Karib: os Kurâ-Bakairi. São Paulo: EDUSP.

BASSO, Ellen. [s.d.]. A Grammar of Kalapalo, A Southern Cariban Language. Tucson.

BASSO, Ellen. 1973. The Kalapalo Indians of Central Brazil. New York: Holt, Rimehart and Wineton Inc.

BASSO, Ellen. 1985. A Musical View of the Universe: Kalapalo Myth and Ritual Performances. Philadelphia: University of Pennsylvania Press.

BASSO, Ellen. 2009. Civility and Deception in Two Kalapalo Ritual Forms. pp. 243-269 in Ritual communication, org. G. Senft e E. Basso. Oxford and New York: Berg.

BERTHOMÉ, François; HOUSEMAN, Michael. 2010. Ritual and Emotions: Moving Relations, Patterned Effusions. In Religion and Society 1: 57-75.

DELEUZE, Gilles; GUATTARI, Félix. 1996. Mil Platôs: Capitalismo e Esquizofrenia (Vol. 3). Rio de Janeiro: Editora 34.

FAUSTO, Carlos. 2008. Donos demais: maestria e domínio na Amazônia. In Mana 14(2): 329366.

FAUSTO, Carlos; FRANCHETTO, Bruna; MONTAGNANI, Tommaso. 2011. Les formes de la mémoire: arts verbaux et musique chez les Kuikuro du Haut Xingu (Brésil). In L'Homme 197: $41-70$.

FRANCHETTO, Bruna. 1986. Falar Kuikuro: Estudo etnolingüístico de um grupo karib do Alto Xingu. Tese de Doutorado. PPGAS/Museu Nacional, Universidade Federal do Rio de Janeiro.

FRANCHETTO, Bruna. 1997. Tolo Kuikúro: Diga Cantando O Que Não Pode Ser Dito Falando. In Invenção do Brasil, Revista do Museu Aberto do Descobrimento: 57-64.

FRANCHETTO, Bruna. 2000. Rencontres rituelles dans le Haut-Xingu: la parole du chef. pp. 481-509 in Les Rituels du Dialogue. Promenades Ethnolinguistiques en Terres Amérindiennes, org. A. Monod-Becquelin \& P. Erikson. Nanterre: Société d'Ethnologie.

FRANCHETTO, Bruna. 2003. L'autre du même: parallélisme et grammaire dans l'art verbal des récits Kuikuro (caribe du Haut Xingu, Brésil). In Amerindia 28: 213-248.

FRANCHETTO, Bruna. 2011. Evidências linguísticas para o entendimento de uma sociedade multilíngue: o Alto Xingu. pp. 3-38 in Alto Xingu: uma sociedade multilíngue, org. B. Franchetto. Rio de Janeiro: Museu do Índio - Funai.

FRANCHETTO, Bruna. 2018. Traduzindo tolo: "eu canto o que ela cantou que ele disse que..." ou "quando cantamos somos todas hipermulheres". In Estudos de Literatura Brasileira Contemporânea 53: $23-43$.

FRANCHETTO, Bruna \& Michael Heckenberger. 2001. Introdução: História e cultura xinguana. Pp. 7-18 in Os Povos do Alto Xingu: História e Cultura, org. B. Franchetto \& M. J. Heckenberger. Rio 
de Janeiro: Editora da UFRJ.

FRANCHETTO, Bruna; MONTAGNANI, Tommaso. 2011. Flûtes des hommes, chants des femmes. Images et relation sonores chez les Kuikuro du Haut-Xingu. In L'Homme 13: 94-111.

GREGOR, Thomas. 1977. The Mehinaku: The Drama of Daily Life in a Brazilian Indian Village. Chicago, Illinois: University of Chicago Press.

GREGOR, Thomas. 1990. Uneasy peace: Intertribal Relations in Brazil's Upper Xingu. pp. 105124 in The Anthropology of War, org. J. Haas. Cambridge: Cambridge University Press.

GUERREIRO, Antonio. 2015a. Ancestrais e suas sombras: uma etnografia da chefia Kalapalo e seu ritual mortuário. Campinas: Editora da Unicamp.

GUERREIRO, Antonio. 2015b. Political chimeras: The uncertainty of the chief's speech in the Upper Xingu. In HAU: Journal of Ethnographic Theory 5: 59-85.

HOUSEMAN, Michael; SEVERI, Carlos. 1998. Naven, ou le Donner à Voir: essai d'interprétation de l'Action Rituelle. Paris: CNRS - Éditions de la Maison des Sciences de l'Homme.

MEHINAKU, Mutua. 2010. Tetsualü: pluralismo de línguas e pessoas no Alto Xingu. Dissertação de Mestrado. Museu Nacional, Universidade Federal do Rio de Janeiro.

MELLO, Maria Ignez C. 2004. Iamurikuma: Música, Mito e Ritual entre os Wauja do Alto Xingu. Tese de Doutorado. Programa de Pós-graduação em Antropologia Social, Universidade Federal de Santa Catarina.

MENEZES BASTOS, Rafael José de. 2013. A Festa da Jaguatirica: uma partitura crítico-interpretativa. Florianópolis: Editora da UFSC.

MENEZES BASTOS, Rafael José de. 1983. Sistemas Políticos, de Comunicação e Articulação Social no Alto Xingu. In Anuário Antropológico 81: 43-58.

NOVO, Marina Pereira; GUERREIRO, Antonio. 2020. Exchange, Friendship and Regional Relations in the Upper Xingu. In Vibrant - Virtual Brazilian Anthropology 17: 1-19.

NOVO, Marina Pereira. 2018. "Esse é o meu patikula": uma etnografia do dinheiro e outras coisas entre os Kalapalo de Aiha. Tese de Doutorado. Programa de Pós-graduação em Antropologia Social, Universidade Federal de São Carlos.

Perrone-Moisés, Beatriz. 2015. Festa e Guerra. Tese de Livre-Docência. São Paulo: Universidade de São Paulo.

RABELLO, Aline Varela. 2013. Marcadores de modalidade epistêmica nas narrativas históricas Kuikuro. Dissertação de Mestrado, Universidade Federal do Rio de Janeiro.

VANZOLINI, Marina. 2015. A flecha do ciúme - o parentesco e seu avesso segundo os Aweti do Alto Xingu. São Paulo: Terceiro Nome.

VIVEIROS DE CASTRO, Eduardo. 2002. Atualização e contra-efetuação do virtual: o processo do parentesco. In: A inconstância da alma selvagem e outros ensaios de antropologia. São Paulo: Cosac \& Naify, pp. 401-455.

VON DEN STEINEN, Karl. 1940. Entre os aborigenes do Brasil Central. São Paulo: Departamento de Cultura. 


\section{KUAMBÜ: POÉTICA E POLÍTICA EM UMA FESTA XINGUANA}

Resumo: O objetivo deste artigo é discutir algumas relações entre poética e política no Alto Xingu, a partir da análise de canções do ritual kuambü entre os Kalapalo (falantes de língua karib daquela região). Por meio da repetição de canções compostas por outros ou de improvisos, o kuambü é um contexto marcado pela expressão musical pública de conflitos, medos, acusações, demandas ou reflexões sobre problemas cotidianos. Este trabalho analisa um fragmento deste repertório, buscando evidenciar algumas das características dos cantos e compreender as relações entre as composições e as situações que lhes deram origem. Pretende-se demonstrar como este ritual, com seu tom ao mesmo tempo grave e jocoso, constitui um momento em que fraturas micropolíticas do cotidiano podem ser expostas e negociadas por meio de uma linguagem poética, revelando uma face geralmente oculta da socialidade do grupo local e criando condições para sua reinvenção.

Palavras-chave: Artes verbais ameríndias. Políticas ameríndias. Ritual. Alto Xingu. Kalapalo.

\section{KUAMBÜ: POETICS AND POLITCS AT A XINGU FESTIVAL}

Abstract: This article intends to discuss some relations between poetics and politics in the Upper Xingu, based on the analysis of songs from the kuambü ritual among the Kalapalo (Carib-speakers of that region). Through the repetition of songs composed by others or improvisations, kuambü is a context marked by the public musical expression of conflicts, fears, accusations, demands or reflections on everyday problems. This work analyzes a fragment of this repertoire, seeking to highlight some of the characteristics of the songs, and to understand the relationships between the compositions and the situations that gave rise to them. It is intended to demonstrate how this ritual, with its tone at the same time serious and playful, constitutes a moment in which micropolitical fractures of everyday life can be exposed and negotiated through a poetic language, revealing a generally hidden face of the sociality of the local group and creating conditions for its reinvention.

Keywords: Amerindian verbal arts. Amerindian politics. Ritual. Upper Xingu. Kalapalo.

RECEBIDO: $02 / 12 / 2019$

APROVADO: $18 / 08 / 2020$ 